\section{THE INSTITUTIONALIZATION OF LABOR MIGRATION IN ISRAEL}

\author{
Rebeca Raijman \\ University of Haifa \\ raijman@soc.haifa.ac.il \\ Adriana Kemp \\ Tel-Aviv University \\ kempadriana@gmail.com
}

Cómo citar este artículo/Citation: Raijman, R. and Kemp, A. (2016). "The institutionalization of labor migration in Israel". Arbor, 192 (777): a289. doi: http://dx.doi.org/10.3989/ arbor.2016.777n1005

Received: September 12th, 2013. Accepted: October 31st, 2014.

ABSTRACT: In this paper we shed light into the process of institutionalization of labor migration in Israel. Specifically, we show the ways by which state regulations created a fertile ground for the creation of a precarious and captive labor force of non-citizens in the Israeli labor market. We focus on the following four main dimensions: (1) the policy of quotas, work permits, and subsidies; (2) the binding system which regulates employment relations; (3) the creation of an infrastructure for manpower agencies that over time became the main stakeholder in the institutionalization of labor migration; and (4) the creation of a complementary mechanism for the "discipline" and control of workers in the form of the deportation policy.

KEYWORDS: Israel; Labor migration; recruitment agencies; binding system; deportation.
LA INSTITUCIONALIZACIÓN DE LA MIGRACIÓN LABORAL EN ISRAEL

Copyright: ( 02016 CSIC. This is an open-access article distributed under the terms of the Creative Commons Attribution-Non Commercial (by-nc) Spain 3.0 License
RESUMEN: El artículo se centra en el proceso de institucionalización del fenómeno de migraciones laborales en Israel. El análisis describe las formas a través de las cuales las regulaciones del estado crearon las condiciones para el surgimiento de una fuerza de trabajo precaria y flexible de extranjeros en el mercado laboral Israelí. Cuatro dimensiones del proceso de institucionalización son analizadas: (1) la fijación de cuotas, otorgamiento de permisos de trabajo y subsidios, (2) el sistema de empleo que regula las relaciones laborales llamado binding, (3) la creación de una infraestructura de agencias de reclutamiento que se benefician de la comodificación del trabajo a través del cobro de tarifas ilegales a los inmigrantes, (4) la implementación del sistema de deportaciones como mecanismo de control y castigo hacia los trabajadores que no respetan las condiciones del contrato.

PALABRAS CLAVE: Israel; Inmigración laboral; agencias de reclutamiento; "binding system"; deportación. 


\section{INTRODUCTION}

Since the late 1970s, the global economy has been characterized by liberalization of trade, services, investment, and capital, but also by transnational movements of people in search of better lives and employment opportunities in developed countries (Castles and Miller, 1993; Cornelius, Martin and Hollifield, 1992; Massey et al., 1998; Sassen, 1988, 1999). While rich countries have outsourced to developing economies part of their industrial production and many of their services (e.g. call centers), there are still sectors in the economy of receiving societies that cannot be outsourced abroad but need the importation of a low-cost and "flexible" labor force to work in what is known as the 3D (dirty, dangerous, and demeaning) jobs in the secondary sector of the economy. Accordingly, there has been a growth in temporary migrant worker programs in a number of receiving countries in North America, Western Europe, Asia, and the Middle East, among them Israel.

Overseas labor migration became a significant feature of Israel society since the middle of the 1990s when a managed migration scheme for low-skilled foreign workers was enacted to replace Palestinian commuters from the Occupied Territories in the secondary labor market (Bartram, 1998). Labor migrants were formally recruited for three main sectors: construction (mainly from Romania, Turkey, Bulgaria, and China), agriculture (from Thailand), and long term (domestic) care - LTC (mainly from the Philippines but lately also from India, Nepal and Sri Lanka). Documented and undocumented labor migrants accounted for $7 \%$ of the total labor force in 2009 (Central Bureau of Statistics, 2010). ${ }^{1}$ Their share within the Israeli labor market ranked Israel at the top of the industrialized economies most heavily dependent on foreign labor (Kemp and Raijman, 2008).

In this paper we shed light into the process of institutionalization of labor migration in Israel. The study is based on a thorough documentary analysis of governmental decisions, parliamentary proceedings of relevant committees - especially the Knesset Committee for Examining the Problem of Foreign Workers - reports produced by the Knesset's Information and Research Center, court rulings, local NGO materials, and data from various publications involving labor migration. Specifically, we show the ways by which state regulations created a fertile ground for the creation of a "precarious" labor force of noncitizens in the Israeli labor market.

\section{THEORETICAL FRAMEWORK}

We argue that systemic features of official labor migration schemes embedded in neo-liberal logics of governance and institutionalized power relations become powerful catalysts in the creation of an unfree labor force taking place first and foremost within the realm of legal labor migration in Israel. Labor migration policy and controls not only regulate the flow of labor migrants but also shape certain forms of "precarious workers" that cluster in particular jobs and segments of the labor market (Anderson 2010).

Anderson (2010) suggests focusing on three main dimensions of immigration controls that lead to the emergence of "precarious" status among migrant workers: (1) the creation of categories of entrant, (2) the influencing of employment relations and, (3) the institutionalization of uncertainty.

(1) The creation of categories of entrant through the policy of quotas and work permits is a core dimension of state immigration controls. The policy of quotas and the provision of permits is a central regulatory means by which the government can determine the extent of labor migration, as well as its nature and composition. As we shall see, the policy of quotas and permits, and the system of subsidies for employing labor migrants in Israel, illustrate two important issues: first, the state's commitment to providing a cheap and unprotected labor force to Israeli employers; and second, the creation of conditions for preferring labor migrants over Palestinian and Israeli workers in the secondary labor market.

(2) The influencing of employment relations: We single out two principal conditions that allow legal mechanisms and practices to influence employment relations: the first is "governing labor migration from a distance," referring to neoliberal configurations of governance that rely on the privatization of labor recruitment, employment and control, and concomitantly on the creation of a large for-profit industry of broker agencies. The institutional logic underlying governing at a distance relies on the devolution of certain functions to organized private actors, but more deeply on logics of "de-responsibilization" of state agencies for labor migrants' rights and conditions (Kemp and Raijman, 2014). As we shall see, practices such as binding, turning a blind eye to charging high recruitment fees, and persistent reluctance to engage in bilateral agreements with sending countries reveal that a major interest of Israeli governments is to ensure migrants' continuous turnover and temporari- 
ness at the expense of workers' rights and labor market situation. This interest is further buttressed by the perception of labor migration as a temporary rather than structural feature of the Israeli labor market and of non-Jewish labor migrants as a potential threat to the identity of the state (Kemp and Raijman, 2008).

(3) The institutionalization of uncertainty through the practice of deportation or the threat of "deportability' has become one of the most important tools for managing and controlling global migration (De Genova, 2002). The deportation policy in Israel is aimed at maximizing the state surveillance over labor migrants' by punishing those who do not comply with the terms of employment. Furthermore, it is the threat of deportation or "deportability" per se that effectively serves to create and sustain a legally vulnerable and precarious labor force of migrants as these are afraid to lose their jobs if they complain about legal violations and cases of fraud (De Genova, 2002). Overall, the three outlined dimensions expose migrant workers to a high degree of regulation and mechanisms of control in the labor market that employers do not have over citizens, thus creating an exploitable, flexible and cheap workforce excluded from the minimal protection of the welfare state (Walia, 2010).

\section{LABOR MIGRATION IN ISRAEL}

In what follows we rely on the three outlined dimensions of immigration controls to analyze the case of labor migration in Israel.

\section{The creation of categories of entrant: The policy of quotas and work permits}

The provision of work permits in Israel differs according to sector of employment. Unlike the construction and agriculture sectors, where labor migrants were quite clearly meant to replace Palestinian workers, the recruitment of labor migrants to the LTC sector created an entirely new employment "niche" that was populated by non-citizen workers (Kemp and Raijman, 2008). ${ }^{2}$ Furthermore, while the agriculture and construction sectors were assigned annually quotas, the LTC sector has no limitations regarding work permits based on the understanding that with longer life expectancy, the need for domestic caregivers for the elderly population would only increase over the years.

In Figure 1 we display trends in work permits issued according to employment sectors. The data show that while in 1996 the construction sector was the largest employer of migrant workers, by 2009 the domestic care sector has became the main recipient of work permits with more than half of the total permits granted this year. The agricultural sector has increased its share by the end of the 1990s and remained pretty much stable during the last decade. The new distribution of quotas and permits among the sectors undoubtedly indicated a change in the balance of forces between employers and state agencies and highlights the government's ability to determine which sectors it wished to benefit (see Raijman and Kemp, 2007).

Figure 1. Distribution of foreign workers, by economic branch

1996

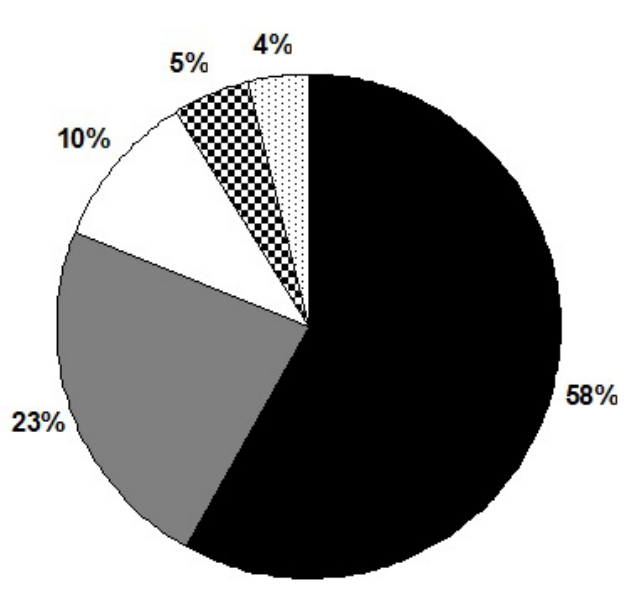

2009

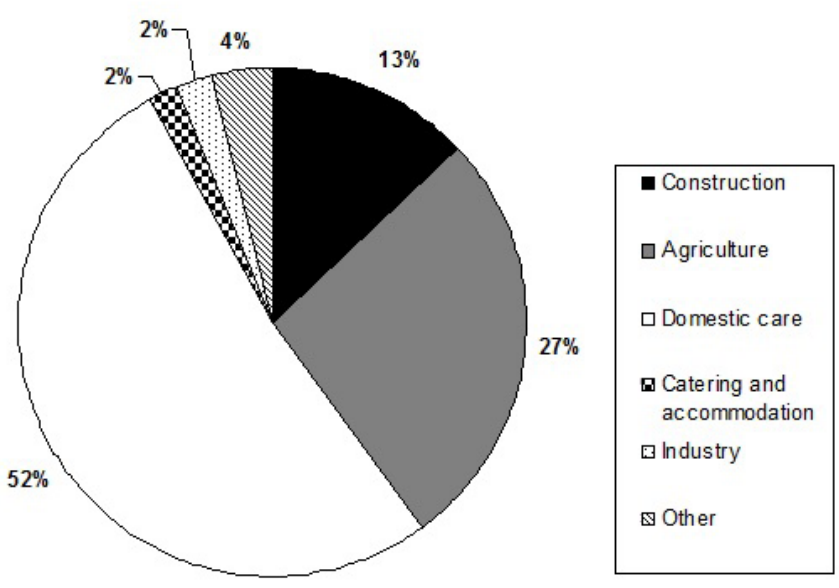


Table 1 presents information regarding countries of origin of labor migrants entering Israel with work permits by country of citizenship in 1995 and 2010. The data show that the ethnic composition of the flows has changed over time, with migrants from Asia increasing their share by the end of the 1990s. This is explained by the changing composition of work permits, which has reduced the number of workers in construction (from East Europe) and increased the number employed in agriculture (from Thailand) and domestic care (mainly from Philippines). Given that the majority of work permits in the latter are granted to women, the changing composition of permits by sector explains the relative increase in the share of women arriving in Israel with work permits over the last decade.
The policy of quotas and permits was complemented by a system of subsidies that drove employers to prefer labor migrants over Israeli workers. Labor migrants' employers are required to make National Insurance payments at a rate of $0.84 \%$ of the worker's gross salary, compared to $4.93 \%$ of the gross salary of Israeli workers. The overall percentage of National Insurance and Health Tax payments incumbent on Israeli workers nowadays reach almost $16 \%$, compared to one or two per cent for a labor migrant.

The policy of quotas and permits, and the system of subsidies for employing labor migrants, illustrate two important issues: first, the state's commitment to providing a cheap and unprotected labor force to Israeli employers; and second, the creation of conditions for preferring labor migrants over Palestinian

Table 1. Arrival of Work Permits by Country of Citizenship and Gender Composition

\begin{tabular}{|c|c|c|c|c|c|c|}
\hline \multirow{2}{*}{$\begin{array}{l}\text { Country of } \\
\text { Citizenship }\end{array}$} & \multicolumn{2}{|c|}{1995} & \multicolumn{2}{|c|}{2000} & \multicolumn{2}{|c|}{2009} \\
\hline & $\%$ & $\%$ Men & $\%$ & $\%$ Men & $\%$ & $\%$ Men \\
\hline Asia-total & 33.1 & 81.0 & 44.1 & 63.0 & 71.8 & 51.0 \\
\hline India & 0.4 & 86.0 & 1.3 & 78.0 & 7.9 & 45.0 \\
\hline Turkey & 7.7 & 94.0 & 3.4 & 98.0 & 3.8 & 99.0 \\
\hline Lebanon & 5.9 & 74.0 & 1.7 & 56.0 & -- & -- \\
\hline China & 2.4 & 97.0 & 5.6 & 96.0 & 4.1 & 94.0 \\
\hline Philippines & 2.9 & 18.0 & 14.6 & 17.0 & 19.2 & 12.0 \\
\hline Thailand & 13.3 & 90.0 & 15.3 & 91.0 & 21.1 & 94.0 \\
\hline \multicolumn{7}{|l|}{ Nepal } \\
\hline Other & 0.5 & 79.0 & 2.1 & 66.0 & 15.8 & 20.8 \\
\hline Africa- total & 0.4 & 75.0 & 1.1 & 51.0 & 0.4 & 90.0 \\
\hline Europe-total & 62.3 & 87.0 & 51.1 & 78.0 & 25.6 & 18.0 \\
\hline Bulgaria & 2.6 & 96.0 & 4.4 & 69.0 & 0.7 & 7.0 \\
\hline USSR (former) & 3.2 & 85.0 & 8.2 & 66.0 & 19.2 & 9.0 \\
\hline Romania & 52.7 & 89.0 & 31.8 & 86.0 & 3.4 & 19.0 \\
\hline Other & 3.8 & 59.0 & 6.8 & 61.0 & 2.3 & 80.8 \\
\hline America-Oceania & 3.0 & 70.0 & 3.3 & 63.0 & 1.9 & 68.0 \\
\hline USA & 2.2 & 69.0 & 2.1 & 67.0 & 1.1 & 77.0 \\
\hline Other & 0.8 & 71.0 & 1.1 & 55.0 & 0.7 & 54.0 \\
\hline Not Known & 2.9 & 81.0 & 0.2 & 78.0 & 0.0 & 0.0 \\
\hline TOTAL & 100.0 & 85.0 & 100.0 & 71.0 & 100.0 & 43.0 \\
\hline & $(78,300)$ & & $(52,200)$ & & $(26,600)$ & \\
\hline Mean Age & 35.0 & & 35.4 & & 36.3 & \\
\hline
\end{tabular}

Sources: Central Bureau of Statistics, 2004, Table 4.10; 2010, Table A 
and Israeli workers in the secondary labor market. This is achieved through the implementation of the binding system and a strong policy of deportation of those residing in Israel without work permits (Kemp and Raijman, 2008).

\section{The influencing of employment relations}

\subsection{The Binding System}

Until 2005, labor migrants' employment was based on what is known as the "binding system."3 According to the binding system, labor migrants are employed by means of individually-allocated permits awarded by the state to employers, and not to the workers themselves. The worker's passport is stamped with the name of the employer for whom $\mathrm{s} /$ he is permitted to work, and $\mathrm{s} / \mathrm{he}$ is forbidden from working for any other employer. Accordingly, the labor migrants' relationship with their employer, to whom work and residence permits for that worker are issued, is crucial to their right to work in Israel: workers may not leave their legal employer for another, and should they do so for any reason whatsoever, their residence permit is invalidated. This immediately makes the worker "deportable" and his/her illegal employer "punishable".

The implementation of the binding system is aimed at maximizing the surveillance over labor migrants' entrance into the country and their activities in the labor market, while minimizing the state's responsibility for the ways in which they are recruited, the terms of their employment, and their living conditions. A number of regulations have been added to the binding system with the aim of restricting the labor migrant's activities to his/her economic function. For instance, in order to prevent extended stays in Israel, there is a principle of rotation that prevents workers from staying for longer than 63 months. ${ }^{4}$ Also, in order to prevent labor migrants from establishing permanent residence and starting a family in Israel, they are forbidden from entering the country with their spouse or any other first degree relatives. Finally, labor migrants are forbidden from having children, as the moment they do so they are faced with two options: either to send the child to their country of origin and continue working until their visa expires or to lose their work and residence permits, and thus become candidates for immediate deportation. ${ }^{5}$

The inherent advantages of the binding system for employers, however, are in no way shared by the workers. Indeed, contract labor has become a fertile ground for the violation of labor migrants' basic social and civic rights, despite laws designed to protect them (Yanay and Borowosky, 1998). Israel has legislated advanced laws regarding workers' rights, including legislation for a minimum wage, working hours, and working conditions. The territorial application of these laws enables them to be applied without discrimination to all inhabitants of Israel, regardless of their legal status in the country. Moreover, Israel is a signatory to international conventions such as the Migration for Employment Convention of the International Labor Organization (1949), ratified by the Knesset in 1953, and the International Convention on the Rights of the Child, ratified in 1991 (Yanay and Borowski, 1998). Even though Israel has wide-ranging and advanced protective labor laws, which also apply to non-citizen workers, the binding system imbues those laws with new meaning that makes it practically impossible to enforce them.

The binding system was the target of public criticism largely been conducted by non-governmental rights organizations throughout the 1990s and into the early 2000s. The struggle against the binding system peaked with the submission of a petition by several NGOs to the Supreme Court of Justice in 2002 to abolish it, calling for an alternative system for the employment of labor migrants. ${ }^{6}$ According to the petition, the binding system violated "fundamental constitutional rights and basic legislative norms, including human dignity and liberty; entitlement to human respect; the right to freedom of contract and association; the freedom of choice and action, and the freedom of occupation, due to the fact that it does not meet the requirements, and specifically the proportionality requirements, of the provisions of the basic law that allow limitations on such basic constitutional rights."

In September 2004, about two years after the petition was submitted, the state announced that a new employment method had been formulated in response to the problems of the binding system which would provide labor migrants with mobility between employers. According to this new system, that was implemented in 2005 in the construction sector, work permits are allocated to manpower corporations, while foreign workers have the practical right to move between employers and registered agencies, as long as they do not move from the sector in which they were permitted to work to another. ${ }^{7}$ Despite the state's claims that the new system annulled the binding system, it merely bound the worker to a new em- 
ployer: the manpower corporation. According to the State Comptroller (2010), although the new method improves supervision of employment conditions a high percentage of corporations violated the rights of workers (delayed wages, not complying with social rights and treatment of permit issues (Raijman and Kushnirovich, 2012).

In 2006, the Israel Supreme Court's accepted the NGOs' petition of 2002 and demanded to abolish within six months the binding system and establish an alternative way for the employment of labor migrants. In its decision the Supreme Court affirmed that the binding system, by violating labor migrants' basic human rights, created a kind of modern slavery and therefore should be annulled. ${ }^{8}$

...Indeed, there is no avoiding a painful and shameful conclusion... that the binding system is creating a modern-day version of slavery. In this binding system, decided on and enforced by the state, the state has bound the guest workers' hands and feet to the employer that has "imported" them to Israel, no less. The guest worker has been transformed from a subject of trial-a person given rights and duties by the courtto an object of trial, as if he were a chattel. The agreement has damaged the guest workers' autonomy as human beings, and has in practice denied them their freedom. According to this agreement, the guest workers have become working machines-especially since the employers have allowed themselves, in contradiction to the law, to pass them from hand to hand- and they have become modern-day slaves, like those human beings who built the pyramids or rowed the Roman empire's ships to war. $^{9}$

Despite such a compelling description of the binding system as modern slavery, until to date the state has not devised and implemented an alternative mode of employment that does not violate migrant workers' basic rights.

In 2010, a reform in the foreign worker employment policy for the LTC sector took place. The new arrangement introduced a 'lighter' version of binding allowing intra-sector mobility between employers and agencies. Yet, as the policy requires new recruits to be fully employed and mandates an allocation of positions to LTC workers already in the country, it has encountered criticism on part of employment agencies, which strongly favor feebringing international recruits. Moreover, following strong lobbying by representatives of the elderly and handicapped groups that oppose the ban on the binding system, an independent bill from 2011 (dubbed by opponents as the "slavery bill") enables the Minister of Interior to limit the geographical area in which migrant care-givers can work and the number of transfers between employers that they can have (Natan, 2011, pp. 6-7). ${ }^{10}$ Thus, after three years in which migrants had been somewhat freer to switch employers, binding has been reinstated, exacerbating the already precarious status of migrant workers in the domestic care-giving sector. As for the agriculture sector, a reform proposed back in 2004 (by the Endorn Committee) to allow visa portability by shifting the personal binding to corporate binding has not been carried out.

The reluctance on part of the state to forego different types of binding and to fully implement government' decisions is explained by strong pressures exerted by employers' lobbies (see Raijman and Kemp, 2007; State Comptroller, 2010). Binding is a particular, albeit extreme, example of more general governance institutional logics whereby the outsourcing of control and management capacities allows public actors to gain greater autonomy from societal demands. The same logic of "outsourcing" drives the withdrawal of public agencies from the screening and recruitment process in the countries of origin. This has led to the creation of a private brokerage industry that operates transnationally and whose expansion relies on profits from recruitment fees collected from the labor migrants before they arrive.

\subsection{Manpower companies and labor recruitment}

One of the central characteristics of labor migration in Israel is the privatization of the recruitment, mediation, administration, and employment of labor migrants to the hands of manpower agencies that serve as a kind of sub-contractor for both the state itself and private employers.

The Israeli state gave the manpower and brokerage agencies a central role by creating the conditions that made manpower agencies "essential", that is, their being the only bodies authorized to come into contact with the authorities in recruiting and employing labor migrants. In fact, the licensing system implemented in 2005 in the construction sector made the activities of the manpower agencies in recruiting and employing labor migrants essential for both workers and employers, as from then on the license for a work permit was given to the corporation and not to the de facto employer or the worker. 
A second way that the state turned manpower agencies into the only body entitled to deal with the authorities in this regard was actually by providing a monopoly in recruiting workers to organized bodies like the Moshav movement in the agriculture sector. ${ }^{11}$ The Moshav Movement's exclusive management of the labor migrant market in the agricultural sector continued uninterrupted until 1998, at which point the government allowed other manpower agencies to enter this profitable "niche".

A third way that the manpower agencies became "essential" in the field of labor migration was through bureaucratic stipulations. This is particularly notable in the domestic care sector, where the entire procedure by which the employer and the worker are brought together - for instance in obtaining a permit - must be carried out through manpower agencies, by order of the Ministry of the Interior. ${ }^{12}$ As a result, and unlike the agriculture and construction sectors in which the state's involvement goes no further than deciding the framework of quotas, issuing work permits, and providing licenses to manpower agencies in the domestic care sector the state has an additional and important role: it pays the salaries of most of the LTC workers by means of nursing care benefits.

\section{A new Israeli industry: Trafficking in human beings?}

Although it was the state that created the conditions for the burgeoning of the manpower agencies, the primary factor behind their prosperity was, naturally enough, purely economic. Even though until 2006 there were laws forbidding agencies from charging recruitment fees from workers, the bulk of the manpower agencies' profits derive precisely from such fees paid by the labor migrants themselves. The long-term lack of law enforcement concerning the activities of Israeli manpower agencies overseas created an expansive migration industry in which recruiting agencies and brokers, both in Israel and countries of origin benefit from the commodification of labor (State Comptroller, 2010).

Since July 2006 Israeli law permits agencies to collect brokerage fees of no more than 3,479 NIS per worker (about $\$ 900$; this sum is updated annually) in addition to travel expenses. But manpower agencies continue to flout the rules and charge sizable recruitment fees, which have even swollen over time. Companies in the Philippines, Thailand, and China (among others) charge fees ranging from $\$ 4,000$ to $\$ 30,000$ for tests, recruitment fees, and air fares. Recruitment fees paid by the workers are shared by manpower agencies in the country of origin and in Israel (Raijman and Kushnirovich, 2012).

The long-term absence of enforcement of the law on the activities of Israeli manpower agencies overseas has created an extensive "grey" industry that provides the basis for trafficking in human beings in Israel (Kemp and Raijman, 2008). In addition to recruitment fees, sometimes the manpower agencies demand that the labor migrants deposit a "guarantee" to ensure that they will not leave their original employer (Pilovsky, 1999). Even though this method of recruitment into debt bondage has been exposed and subjected to public criticism, it is still highly active. In February 2003 a scandal involving Bulgarian workers hit the headlines. They had been recruited by a manpower agency, which demanded that each worker deposit a guarantee of $\$ 5,000$ and that they mortgage their homes to the agency to ensure their fulfillment of their obligations to the contractors. The same company even promised to compensate the contractors $\$ 5,000$ for every worker dared to leave them (Kemp and Raijman, 2008).

Following the intervention of Israeli NGOs, these issues came to the attention of the US State Department in 2003. A State Department report defined the situation in Israel, whereby manpower agencies required labor migrants to mortgage their properties to ensure that they uphold their labor contract in Israel, as "debt bondage," and demanded that the Israeli government look into it and take care of the matter immediately. Since 2003, the US State Department report on Trafficking in Persons has ranked Israel in Tier 2 with the group of countries in which the phenomenon is strongly marked: "some foreign laborers enter into Israel for labor under conditions that constitute trafficking. Some laborers are subjected to debt bondage and restriction on their movements, including employer confiscation of their passports" (U.S. Department of State, 2006, p. 194). Follow-up reports published by the State Department since 2003 maintained that despite an improvement in the Israeli government's efforts to combat human trafficking, it was still not doing enough to meet even the minimal standards to eradicate it. ${ }^{13}$

In order to combat this phenomenon, the Israeli government decided to sign bilateral agreements with some countries from which migrants were usually recruited. ${ }^{14}$ So far bilateral agreements were signed with Thailand to recruit workers for the agriculture sector and with Bulgaria, Moldova, and Rumania to recruit workers for the construction sector. 
Under the agreement signed with Thailand in $2010,{ }^{15}$ a newly created framework of cooperation, the Thailand-Israel Cooperation on the Placement of Workers (TIC), is in charge of the recruitment of migrant workers in agriculture, and the management and supervision of the recruitment process is conducted by the IOM (International Organization for Migration). Israeli and Thai private agencies are no longer directly involved in such recruitment. Israeli local agencies are now responsible for the workers only after their arrival, a service for which they are permitted to charge a fee set in advance. ${ }^{16}$

Research conducted to evaluate the impact of bilateral agreements has shown a dramatic reduction in the recruitment fees paid by the migrants. Thai migrant workers paid circa $\$ 9,000$ before the implementation of the bilateral agreement (BA). However, after the implementation of the BA the "cost of migration" - the total expenses (in US dollars) - has been extremely reduced to an average $\$ 1,200$ for those arriving before March 2013 and circa \$2,200 for those arriving after March 2013, when an additional payment of 2,724 N.I.S (approximately \$780) to the local manpower agencies in Israel was approved. ${ }^{17}$

Bilateral agreements have been signed with Bulgaria, Moldova and lately with Romania to recruit migrant worker in construction sector. Bulgarian and Moldovan workers do not pay recruitment fees at all but need only take care of costs associated with flight tickets, medical examinations, and preparation and translation of documents, among others. Therefore the cost of migration is rather low, $\$ 500$ on average, if we compare it with the amounts of money paid by Chinese workers arriving though private recruitment: 22,000 US dollars (see Raijman and Kushnirovich 2012). The gap in the "before" and "after" payments made by the migrant workers is a clear indicator of the impact of the new system of recruitment on the fees paid by the migrants (Raijman and Kushnirovich 2015). It should be noted that a bilateral agreement has been signed with Nepal (August 2015) but still most of the recruitment of workers in the caregiving sector is conducted through private agencies.

\section{The Institutionalization of Uncertainty: Deportation Policy}

One of the most important pillars in the policy of labor migration is the deportation policy implemented among migrants residing in Israel without work permits. During the last 15 years, labor migrants without permits comprised between forty to fifty percent of the total population of migrant workers in Israel. There are three main pathways to becoming a foreign worker without a permit: (1) tourists who overstay their visa, (2) foreign workers that lose their work and residence permits by leaving the employer to whom they are bound, (3) foreign workers with permits that overstay their work visa. ${ }^{18}$

The primary method for dealing with the so called illegal labor migrants was to turn their deportation into a systematic policy. ${ }^{19}$ Between 1995 and 2008 over 76000 migrant workers were deported with 2003 and 2004 constituting the peak years (Bar Zuri, 2009). The most significant organizational and institutional expression of the deportation policy was the establishment of the new Immigration Administration in 2002 (Gill and Dahan, 2006). From the outset, the Immigration Police had a double function: on the one hand, it was an enforcement mechanism, and on the other it was an apparatus for disseminating information, primarily to employers in Israel, who had been enjoying a large and accessible pool of undocumented labor migrants who were not subject to the government's quota policy. Accordingly, since its establishment the Immigration Police has not refrained from detailing to the public the supposed threats latent in the phenomenon: an economic threat ("the illegal foreign workers have a significant impact on natives' unemployment"; "there is a financial drain from Israel to their countries of origin"; "they hardly pay taxes, which creates a heavy burden on infrastructure without assisting in its maintenance"); a demographic and national threat ("demographically speaking, a 'state' within a 'state' is taking shape"; "the Jewish character of the state is being damaged by intermarriage"); and even a security threat ("because of their lack of affinity to Israel, the illegal residents are liable to be a platform for security crimes and hostile destructive activity" (Gill and Dahan 2006).

However, the concrete consequences of this crusade against the phenomenon of "illegal employment" mostly impacted on illegal immigrants and their families, and much less on their Israeli employers. This is clearly indicated by the Immigration Authority's budget, of which, in 2004 , only one per cent was allocated for activities against employers who violated labor migrants' rights (for instance, by confiscating their passports, trafficking in human beings, providing unbefitting living and working conditions, holding wages back, and so on), while most of the resources were devoted to arresting and deporting the migrants themselves.

The Immigration Police represented an important turning point in the scope of the deportation of un- 
documented labor migrants: according to its own reports, since its establishment in September 2002, 118,105 people have left Israel, 40,000 of whom were deported. Mass deportation operations were carried out after migrants had been arrested following raids on houses, places of work, buses, and shopping centers, and even after street chases. Such arrests, many of which were accompanied by callous violence on the part of the police and the crude violation of rights, became an everyday spectacle (Gill and Dahan, 2006). It was not only the sheer quantity of deportations that changed, but also the target groups. Recognizing the central role played by community networks and organizations in the lives of undocumented migrants, police activities were not only directed at individuals, but also at dismantling the communities themselves. Expansive police and intelligence work was devoted to locating and deporting community leaders, and raiding places where labor migrants held community gatherings and spent their leisure time (see e.g. Sinai, 2004, 2005; Wurgaft, 2004).

One of the main consequences of the establishment of the Immigration Police, therefore, was that state mechanisms singled out labor migrants as the scapegoat for Israel's economic and social ills. This enabled the government to hide from the public the very conditions that had led to the phenomenon of "foreign workers" in the first place. Indeed, it was the state itself that had allowed the massive recruitment of cheap labor migrants and offered a series of incentives for preferring them over other workers. Meanwhile, it had consistently turned a blind eye to their shameful working conditions, and ignored the unintended consequences that accompanied the recruitment of labor migrants when some of them become migrants on a permanent basis. By detaching decisions and government policy from the phenomenon of the "illegal aliens", and by presenting them as appearing both to break the law and violate Israel's sovereignty, the government could absolve itself of all responsibility (Kemp and Raijman, 2008).

\section{CONCLUSIONS}

This paper has outlined the ways by which labor migration has been institutionalized in Israel and highlighted the mechanisms through which a pool of precarious workers has emerged in the local labor market. By paving the way for the massive recruitment of labor migrants, the state was able to deliver political and economic benefits to employers (in the construction and agriculture sector) and compensate them for the forced withdrawal of Palestinian workers from the Israeli labor market. The state was able to do this through the ordered provision of imported cheap labor and the creation of a significant pool of non-free workers through the binding system and related laws. These laws effectively subject workers to a high degree of regulation, giving employers mechanisms of control that they do not have over citizens. Through enforcing atypical employment relations such as fixed term contracts and direct dependence on employers on legal status, these regulations create a group of workers that are more desirable as employees to local employers (Anderson, 2010).

The liberalization of the Israeli labor market taking place since the middle of the 1980s also enabled the state to absolve itself of any responsibility for the migrant workers, and instituted the conditions for the emergence of a stratum of social actors -employers and manpower agencies- who would reap the benefits of this new state of affairs. Stringent state regulations applied to labor migrants (such as the binding system and the threat of automatic deportation), coupled with flimsy state prosecution of lawbreaking employers, have provided the means and the opportunity for the legal labor migration system to become into a captive labor force, sometimes even degenerating into a human trafficking industry (Kemp and Raijman, 2014). However, the implementation of bilateral agreements in the construction and agricultural sectors has had a strong impact both on the process of recruitment of workers. The whole recruiting process is monitored through its various stages by national offices (Ministry of Labor in Thailand, Bulgaria, and Moldova and the PIBA in Israel) and international agencies (IOM in Thailand), and the fees have been dramatically reduced lowering the debts which migrants incurred to finance their move to Israel. This new situation allows to workers to feel free to move between employers, complain in case of rights violations, or even return to their countries of origin before the end of the contract (see Raijman and Kushnirovich, 2015). The successful experience of bilateral agreements in the agriculture and construction sectors in lowering the "cost of migration" suggests the need to implement the same type of arrangements in the caregiving sector in which still migrants workers are asked to pay exorbitant fees to come to work in Israel. It should be noted that the impact of the implementation of bilateral agreements is less evident with regard to migrant workers' rights and living and working conditions (Raijman and Kushnirovich, 2015). 
Finally, the current migration regime in Israel is highly exclusionary regarding non-Jews (those not covered by the amendment to the Law of Return) and also removes a priori any possibility of incorporation for nonJewish migrants. Unwillingness to accept non-Jewish immigrants is expressed through exclusionary immigration policies (especially limitation of family reunion and refusal to secure residence status), restrictive naturalization rules, and a double standard: exclusionary model for non- Jews as against an "acceptance- encouragement" model for Jews (Raijman, Semyonov and Schmidt, 2003). In that sense, Israel's migration policy towards labor migrants reflects the state's never-ending anxiety about a changing ethnoscape that may pose a threat to its Jewish character. Labor migrants may thus be considered "margizens", that is, a new category of people who, denied membership in the host society, remain excluded in legal, social, cultural and political terms (Kemp et al., 2000).

\section{NOTES}

1. Palestinian workers from the West Bank and Gaza Strip were recruited following the Six Day War in 1967, to perform mostly menial, low-status, manual jobs in the Israeli labor market. By 1987 they comprised seven percent of the entire Israeli labor force (Semyonov and Lewin-Epstein, 1987). The outbreak of the first Intifada (Palestinian uprising) in 1987 created a shortage of labor in low-status positions, when the entry of noncitizen Palestinian workers into Israe was prevented because of imposed closure or self-imposed strikes. These events set the initial stage for the organized recruitment of overseas labor migrants (Bartram, 1998).

2. The Long Term Care Insurance Act, which came into effect in April 1988, marked the starting point for largescale migration of caregiving workers into Israel. The Act permitted those in need of geriatric care to hire nonIsraeli care workers, allowing the elderly to continue living in their familiar familial and social environment (Ofir et al., 2001).

3. This arrangement is rooted in the Entry into Israel Law, 1952, the Employment Service Law, 1959, as well as in Clause $1 \mathrm{M}(\mathrm{a})$ of the Foreign Workers (Prohibition of Unlawful Employment and Assurance of Fair Conditions) Law, 1991

4. In June 2004, a new procedure was implemented, the initiative of Minister of the Interior, Avraham Poraz, by which labor migrants in the domestic care can be given a work permit for more than 5 years, with no time limit, if a professional opinion is proffered that asserts that taking the worker away from his or her patient would cause damage to the latter.
5. In 2005 , a group of human rights organizations appealed to the Supreme Court of Justice against this procedure, which they characterized as discriminating between the labor rights of Israeli and non-Israeli women. The Israel's Supreme Court of Justice verdict (11437/05) in 2011 overturned the policy, calling on the Ministry of Interior to take steps towards formulating a new one. So far, however, the Israeli government has determined no specific procedures regarding the terms of work and living conditions of migrant women who gave birth to a child and wish to continue to work and live with their child in Israel.

6. SCJ $4542 / 02$. The petition to cancel the binding system was submitted by the following organizations: Worker's Hotline, The Hotline for Migrant Workers, The Association for Civil Rights in Israel, Physicians for Human Rights, The Adva Center, and Commitment to Peace and Social Justice - which runs a Center for the Rights of the Unemployed - and the Tel Aviv University Welfare and Law Program.

7. Report of the Inter-ministerial Committee on "The Mode of Employing Foreign Workers in Israel and Conditions for Issuing Permits," August 2004, 8.

8. Supreme Court Petition 4542/02:21. For a discussion of the legal aspects of the employment of labor migrants in Israel, and of the role of the courts, see Sitbon, 2006.

9. Judge Heshin, Supreme Court Petition 4542/02.

10. The bill, which passed in 2011, introduced an amendment to the Entry to
Israel Law (Amendment N. 21, 57712011 SB 926). Its provisions are likely to increase care-givers' dependency on their employers, thereby deterring workers from claiming their rights or leaving abusive employers. Moreover, the bill is inconsistent with the Hight Court of Justice's ruling against binding (HCJ 4524/02).

11. Thus, for example, in the agricultural sector, the Moshav Movement came to have the power of attorney of all the employers in the field of agriculture. Some argue that the considerable profits made throughout the 1990s by the Moshav Movement from its new role as the umbrella organization that regulated the recruitment and employment of labor migrants enabled it to extract itself from a deep financial crisis (Pilovsky, 1999).

12. On the problems with this arrangement, see the Protocol of the Special Knesset Committee for the Problem of Foreign Workers, 3.7.01, 10.

13. For a detailed examination of trafficking in labor migrants in Israel see Worker's Hotline, Annual Report for 2002, www.kavlaoved.org.il.

14. The agreement follows Government Resolution 3453 according to which migrant construction workers shall be recruited only on the basis of bilateral agreements. http://www.piba. gov.il/SpokesmanshipMessagess/ Pages/2011-30011.aspx (accessed January 20, 2012)

15. It should be noted that although the government resolution regarding the signing of a bilateral agreement with Thailand was passed in 2005, the current agreement was signed in 
December 2010 and became operational only in May 2012. The bilateral arrangement has been challenged by private recruitment agencies in the agricultural sector, which have pressured the Minister of Interior to stop its implementation. Despite local pressure, the bilateral agreement became operational in May 2012.

16. Israeli manpower agencies deal with issues of health, mobility between employers and any other issues associated with migrants' needs during their stay in Israel.

17. See Employment Service Regulations (Payments from Labor Seekers to Mediators), 2006. www.nevo.co.il/ Law_Word/law01/999_625. Doc. Accessed, June, 11, 2014.

18. According to Bar Zuri (2005) from the total number of foreign migrants

\section{REFERENCES}

Anderson, B. (2010). Migration, Immigration Controls and the fashioning of Precarious Workers. Work, Employment and Society, 24, 2, pp. 300-317. http://dx.doi. org/10.1177/0950017010362141

Bartram, D. (1998). Foreign Workers in Israel: History and Theory. International Migration Review, 32, pp. 303-325. http:// dx.doi.org/10.2307/2547185

Bar Zuri, R. (2005). Chinese Workers Employed in Israel without Work Permits. Jerusalem: The Ministry of Industry, Employment and Commerce.

Bar Zuri, R. (2009). Undocumented Foreign Workers who were deported from Israel in 2008 [on line]. Available from http://www.tamas.gov.il/NR/ rdonlyres/10E53F4E-D8D0-41B2-B1925E40BBE100D8/0/zarim2008.pdf

Castles, S. and Miller, M. (1993). The Age of Migration: International Population Movements in the Modern World. New York: Guilford.

Central Bureau of Statistics. (2010). Press Release. 27.7.2010.

Cornelius, W. A., Martin, P. L and Hollifield, J. F. (eds.). (1992). Introduction: The Ambivalent Quest for Immigration Control. Controlling Immigration: A Global Perspective. Stanford: Stanford University Press, pp. 3-42.

De Genova, N. (2002) Migrant "Illegality" and Deportability in Everyday Life. Annual Review of Anthropology, 31, pp. 419-447. http://dx.doi.org/10.1146/annurev.anthro.31.040402.085432

Fisher, H. (1999). Foreign workers: Report situation, legal framework and public policy. In Nathanson, R. and Achdut, L. (eds.). The New workers. Wage earners from foreign countries in Israel. Tel Aviv: Hakbbutz Hamehuchad, pp. 13-40.
Gill, A. and Dahan, Y. (2006). Between NeoLiberalism and Ethno-Nationalism: Theory, Policy, and Law in the Deportation of Migrant Workers in Israel. Law and Government in Israel, 10, 1, pp. 347 386. [In Hebrew].

Kemp, A., Raijman, R., Resnik, J. and Schammah-Gesser, S. (2000). Contesting the Limits of Political Participation: Latinos and Black African Migrant Workers in Israel. Ethnic and Racial Studies, 23, 1, pp. 94-119. http://dx.doi. org/10.1080/014198700329141

Kemp, A. and Raijman, R. (2008). 'Workers' and 'Foreigners': The Political Economy of Labor Migration in Israel. Jerusalem: Van-Leer Institute and Kibbutz Hamehuhad. [In Hebrew].

Kemp, A. and Raijman, R. (2014). Bringing in State Regulations, Private Brokers, and Local Employers: A Meso-Level Analysis of Labor Trafficking in Israel. International Migration Review, 48, 3, pp. 604-642. http://dx.doi.org/10.1111/ imre.12109

Massey, D. S., Arango, J., Hugo, G., Kouaouci, A. Pellegrino, A. and Taylor, J. E. (1998). Worlds in Motion: Understanding International Migration at the End of the Millenium. Oxford: Clarendon Press.

Natan, G. (2011). Handling the Issue of Collecting Illegal Recruitment Fees from Foreign Workers. Jerusalem: The Knesset Information and Research Center. [In Hebrew]. Available from http:// www.knesset.gov.il/mmm/data/pdf/ m02210.pdf

Ofir, Y. H. Daskal, N. Dror, B. S. Holtzman, O. Hirshfeld, and Salomon, H. 2001. Foreign Workers in the Nursing Care Sector. Discussion Paper 7.01. Jerusalem: Ministry of Labour and Welfare, Manpower Programming Authority. without work permits awaiting deportation in the prison , 41 percent reported entering the country with a work permit and 59 percent with a tourist visa.

19. See Government Resolution Nos. 238 (August 1996); 717 (November 1996); 2201 (June 1997); 12 (May 1998); 4361 (October 1998); 2213 (August 2000); 642 (September 2001); 1141 (December 2001).
Pilovsky, L. (1999). Present Absentees: The Analysis of the functioning of manpower agencies for labor migrants' recruitment, and the relationship between them and the authorities. In Nathanson, R. and Achdut, L. (eds.). The New workers. Wage earners from foreign countries in Israel. Tel Aviv: Hakibbutz Hamehuchad, pp. 41-89.

Raijman, R., Semyonov, M. and Schmidt, P. (2003). Do Foreigners Deserve Rights? Public Views towards Labor Migrants in Germany and Israel. European Sociological Review, 19, pp. 379-392. http:// dx.doi.org/10.1093/esr/19.4.379

Raijman, R. and Kemp, A. (2007) Labor migration, managing the ethno-national conflict, and client politics in Israel. In Willen, S. (ed.). Transnational migration to Israel in global comparative context. Lanham, Maryland: Lexington Books, pp. 31-50.

Raijman, R. and Kushnirovich, N. (2012). Labor Migrant Recruitment Practices in Israel. Final Report. Ruppin Academic Center and Center for International Migration and Integration CIMI [On line]. Available from https://www.researchgate.net/publication/236000371_Labor_Migrant_Recruitment_Practices_ in_Israel_FINAL_REPORT

Raijman, R. and Kushnirovich, N. (2015). Recruitment of Migrant Workers in Agriculture and Construction in Israel: the Impact of Bilateral Agreements. Final Report. Ruppin Academic Center and Center for International Migration and Integration CIMI. [On line]. Available from http://www.justice.gov.il/ En/Units/Trafficking/MainDocs/impactbilateral\%20agreements.pdf

Sassen, S. (1988). The Mobility of Labor and Capital: A Study in International Investment and Labor Flow. Cambridge: Cambridge University Press. http://dx.doi. org/10.1017/CBO9780511598296 
Sassen, S. (1999). Guests and Aliens. New York: New York Press.

Semyonov, M. and Lewin-Epstein, N. (1987). Hewers of Wood and Drawers of Water: Noncitizen Arabs in the Israeli Labor Market. New York: ILR Press.

Sinai, R. (2004). Foreigners are arrested so as to give up their friends. Haaretz, 16.2.2004, A1 and A11.

Sinai, R. (2005). After two and half years, it is much harder for the Immigration Police to find people to deport. Haaretz, 3.2.05, A1 and A5.
Sitbon, O. (2006). The role of courts in Israel and France in designing the policy on migrant workers. Law and Government in Israel, 10, 1, pp. 273-346. [In Hebrew].

State Comptroller. (2010). Annual Report. Jerusalem.

U.S. Department of State. (2006). Victims of Trafficking and Violence Protection. Act of 2000: Trafficking in Persons Report. http://www.state.gov/g/tip/rls/ tiprpt/2006/

State Comptroller (2010). Annual Report of the State Comptroller, 61. Available from http://old.mevaker.gov.il/serve/ site/english/epublic.asp

Yanay, U. and Borowosky, A. (1998). Foreign workers in Israel: Rights and access to welfare services. Social Security, 53, pp. 59-78. [In Hebrew].

Walia, H. (2010). Transient Servitude: Migrant Labour in Canada and the Apartheid of Citizenship. Race\&Class, 52, 1, pp. 71-84. http://dx.doi. org/10.1177/0306396810371766

Wurgaft, N. (2004). Goodbye and thank you for the humiliation. Haaretz, 5.4.2004, B9. 